\title{
Kepatuhan Wajib Pajak Pasca Aturan PP No 23 Tahun 2018 pada UMKM Ekowisata Desa Singapadu
}

\author{
Cokorda Krisna Yudha1 \\ Fakultas Ekonomi dan Bisnis \\ Universitas Warmadewa, Indonesia \\ Email: yudhacokkrisna@gmail.com
}

\author{
Cok Istri Ratna Sari Dewi ${ }^{2}$ \\ Fakultas Ekonomi dan Bisnis \\ Universitas Warmadewa, Indonesia
}

\begin{abstract}
ABSTRAK
Penelitian ini bertujuan untuk menganalisis kepatuhan wajib pajak pascaaturan PP No 23 Tahun 2018 pada pelaku UMKM Ekowisata di Desa Singapadu Kaler dan Singapadu Tengah. Berdasarkan data Direktorat Jendral Pajak (DJP), jumlah pembayar PPh Final UMKM masih sangat rendah jika dibandingkan dengan total jumlah pelaku UMKM di Indonesia. Sosialisasi dan pengetahuan wajib pajak menjadi faktor penting yang memengaruhi kepatuhan Wajib Pajak mengingat besarnya potensi UMKM dalam menyumbangkan kontribusinya dalam hal penerimaan perpajakan. Penelitian ini menggunakan metode penelitian kualitatif. Pengujian validitas data dilakukan dengan menggunakan triangulasisumber. Hasil penelitian menunjukkan angka kepatuhan wajib pajak pasca aturan PP No23 Tahun 2018 pada pelaku UMKM di desa Singapadu mencapai angka 85 persen. Kurangnya sosialisasi secaralangsung da ri pihak KPP Pratama Gianyar juga menjadi temuan dalam penelitian ini, sehingga pengetahuan tentang aturan PP No 23 tahun 2018 belum banyak diketahui oleh pelaku usaha di desa tersebut.
\end{abstract}

Kata Kunci: Kepatuhan Wajib Pajak; PP 23 tahun 2018; UMKM.

\section{Taxpayer Compliance of Ecotourism Micro Small Medium Enterprises (SMEs) Post Government Regulation No. 23/2018 in Singapadu Village}

\begin{abstract}
This study aims to analyze the compliance of taxpayer post government regulation No. 23/2018 on Ecotourism MSEs in Singapadu Kaler and Singapadu Tengah Village. Based on data from the Directorate General of Taxes, the number of Final Tax payers is still very low compared to the total number of SMEs in Indonesia. Socialization and taxpayer knowledge are the main factors that affect taxpayer compliance given the large potential of MSEs in contributing to tax revenue. This study used qualitative research methods. The results showed the taxpayer compliance rate post governmentregulation No. 23/2018 in Singapadu village reached 85 percent. The lack of socialization lead to taxpayer knowledge about the regulation is not widely known by SMEs in the village.
\end{abstract}

Keywords: $\quad$ Taxpayer Compliance; Government Regulation No. 23/2018; SMEs.

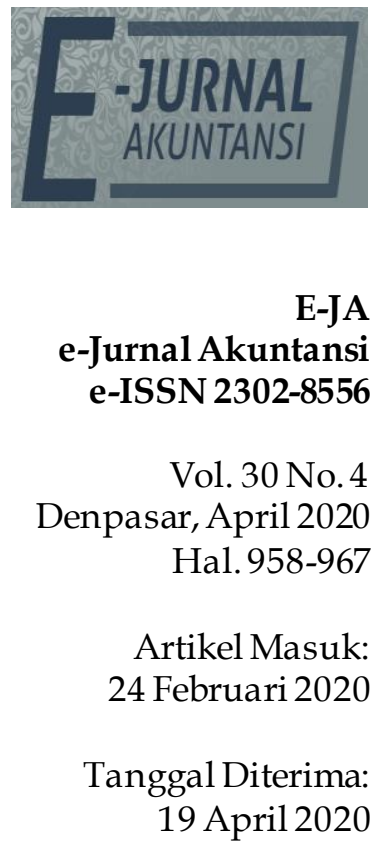

19 April 2020 


\section{PENDAHULUAN}

Pajak dapat diartikan sebagai iuran rakyat kepada kas negara berdasarkan Undang-Undang (yang dapat dipaksakan) dengan tidak mendapat jasa timbal balik (kontraprestasi) yang langsung dapat ditunjukkan dan yang digunakan untuk kepentingan umum (Mardiasmo, 2009). Pajak merupakan salah satu sumber utama penerimaan negara yang digunakan dalam menopang pembiayaan pembangunan daerah. Apabila penerimaan pajak terus mengalami peningkatan maka proses pembangunan dapat berjalan dengan lancar. Berdasarkan data APBN 2018 mengenai target penerimaan perpajakan dari Kementerian Keuangan Republik Indonesia, terjadi peningkatan dari tahun sebelumnya sebesar 10 persen menjadi 1.618,1 triliun di tahun 2018. Peningkatan penerimaan pajak dalam 5 tahun terakhir menandakan bahwa kesadaran masyarakat mulai terbentuk dalam membayar pajak yang ditunjukan dalam Tabel 1.

Tabel 1. Target Penerimaan Pajak di Indonesia

\begin{tabular}{ccc}
\hline Tahun & $\begin{array}{c}\text { Target } \\
\text { PenerimaanPajak }\end{array}$ & Persentase Kenaikan \\
\hline 2014 & $1.146,9$ triliun & $6,5 \%$ \\
2015 & $1.240,4$ triliun & $8,2 \%$ \\
2016 & $1.285,0$ triliun & $3,6 \%$ \\
2017 & $1.472,7$ triliun & $14,6 \%$ \\
2018 & $1.618,1$ triliun & $10 \%$ \\
\hline
\end{tabular}

Sumber:https://www.kemenkeu.go.id/apbn2018,2019

Sektor pajak mayoritas bersumber dari sektor riil ekonomi. Salah satuny a adalah Usaha Mikro Kecil dan Menengah (UMKM). Pertumbuhan UMKM di Indonesia dari tahun ke tahun semakin bertambah. UMKM mendominasi struktur usaha yang ada di Indonesia sekitar 98,8 persen. Dari total tenaga kerja, 96,99 persen bekerja di sektor usaha UMKM. Bahkan, 60,3 persen Produk Domestik Bruto di Indonesia saat ini berasal dari UMKM. Berdasarkan data dari Kementerian Koperasi dan Usaha Kecil Menengah (Kemenkop UKM), sebanyak 3,79 juta UMKM sudah memanfaatkan platform online dalam memasarkan produknya. Jumlah ini berkisar 8 persen dari total pelaku UMKM yang ada di Indonesia, yakni 59,2 juta. Kenaikan jumlah pelaku UMKM yang begitu pesat menimbulkan potensi penerimaan pajak bagi pemerintah. Transaksi-transaksi yang timbul dari UMKM ini tentu menimbulkan kewajiban perpajakan bagi pelaku usahanya. Namun besarnya jumlah pelaku UMKM ternyata belum sebanding dengan penerimaan pajak dari UMKM. Usaha menengah dan besar masih menjadi penyumbang pajak terbesar di Indonesia. Berdasarkan data Direktorat Jendral Pajak (DJP, 2018), hingga 7 Desember 2018, jumlah pembay ar PPh Final UMKM mencapai 1,69 juta Wajib Pajak dengan nominal sebesar Rp 5,37 triliun. Jumlah tersebut menunjukkan bahwa kepatuhan Wajib Pajak UMKM masih sangat rendah jika dibandingkan dengan total jumlah pelaku UMKM di Indonesia yakni 59,2 juta. Beberapa penyebabnya adalah fakta bahwa DJP lebih fokus pada wajib pajak besar sedangkan pengawasan kepada pelaku UMKM belum secara optimal dilakukan dan kepatuhan pajak pelaku UMKM juga masih rendah (Endrianto, 2015). 
Tabel 2. Rasio Kepatuhan Penyampaian SPT Tahunan PPh di Indonesia

\begin{tabular}{ccc}
\hline Tahun & $\begin{array}{c}\text { WajibPajakTerdaftar } \\
\text { WajibSPT }\end{array}$ & Rasio Kepatuhan \\
\hline 2013 & 17.731 .736 orang & $56,22 \%$ \\
2014 & 18.357 .833 orang & $59,13 \%$ \\
2015 & 18.159 .840 orang & $60,44 \%$ \\
2016 & 20.165 .718 orang & $60,78 \%$ \\
2017 & 16.598 .887 orang & $72,64 \%$ \\
\hline
\end{tabular}

Sumber: https:// www.pajak.go.id/id/laporan-tahunan-2017,2019

Tabel 2. menunjukkan rasio kepatuhan wajib pajak dalam kurun waktu 5 tahun terakhir selalu mengalami peningkatan atas kepatuhan pajak. Kepatuhan pajak (tax compliance) adalah wajib pajak yang mempunyai kesadaran dan tanpa paksaan untuk memenuhi kewajiban pajaknya sesuai dengan ketentuan yang berlaku (James \& Alley, 2002). Kepatuhan pajak dapat dilihat dari rasio kepatuhan wajib pajak dalam menyampaikan SPT Tahunan. Berdasarkan data dari laporan tahunan DJP, rasio kepatuhan dalam penyampaian Surat Pemberitahuan (SPT) tahunan Pajak Penghasilan (PPh) pada tahun 2017 mencapai 72,64 persen. Rasio kepatuhan tersebut merupakan perbandingan antara jumlah SPT Tahunan PPh yang diterima dalam suatu tahun pajak tertentu dengan jumlah Wajib Pajak Terdaftar Wajib SPT pada awal tahun. Adapun Wajib Pajak Terdaftar Wajib SPT yang dimaksud adalah wajib pajak badan, wajib pajak orang pribadi karyawan dan wajib pajak non karyawan. Kepatuhan wajib pajak dapat dipengaruhi oleh beberapa faktor. Simanjuntak dan Mukhlis (2012) menyatakan bahwa beberapa faktor yang dapat mempengaruhi kepatuhan Wajib Pajak antara lain pemahaman peraturan perpajakan, tarif pajak, sanksi dan keadilan. Tarif pajak mempunyai pengaruh signifikan terhadap kepatuhan Wajib Pajak (Lazuardini, Susyanti, \& Priyono, 2018). Dengan demikian kepatuhan Wajib Pajak juga dapat tercapai apabila ada penetapan tarif yang jelas, selain itu tarif pajak juga harus bersifat adil dalam menentukan subjek dan objek pajaknya.

Kewajiban dalam menyelenggarakan pembukuan disebut sebagai salah satu kendala bagi sebagian besar UMKM. Kendala pengembangan UMKM selain rendahnya pendidikan dan kurangnya pemahaman teknologi informasi, juga kendala dalam penyusunan laporan keuangan ( Rini, 2015). Sebagian besar UMKM memiliki kendala dalam hal administrasi dan laporan keuangan sehingga tidak memiliki laporan pembukuan yang baik. Perkembangan UMKM yang dimulai dari usaha individu dan kemudian berkembang hingga berbentuk badan dengan skala kecil menengah. Oleh sebab itu, mereka tidak memiliki pengetahuan cukup dalam bidang seperti pembukuan, administrasi, dan pengetahuan tentang perpajakan. Faktor tersebutlah yang berdampak terhadap kurangnya tingkat kepatuhan pajak secara pribadi (Inasius, 2014). Di negara lain terjadi hal serupa mengenai kebijakan perpajakan yang memberatkan bagi UMKM sehingga berpengaruh terhadap pertumbuhan sektor ini. Penelitian Mwangi dan Nganga (2006) menunjukkan UMKM di Nigeria yang memiliki potensi tinggi namun mengalami kesulitan besar karena kebijakan pajak yang memberatkan mereka.

Peraturan perpajakan yang sangat kompleks berpengaruh negatif terhadap kemampuan bertahan dan kemampuan membayar pajak pada wajib 
pajak UMKM. Pemerintah harus memberi keseragaman perpajakan untuk pengusaha UMKM, dan memperhatikan kemampuan perusahaan guna menentukan kebijakan perpajakan (Gbegi \& Adebisi, 2013). Kebijakan perpajakan bagi UMKM di Nigeria dinilai sangat berat sebab tarif pajaknya yang tinggi, pajak berganda, peraturan perpajakan yang rumit dan kurangnya edukasi maupun informasi yang berkaitan dengan perpajakan (Atawodi \& Ojeka, 2012). Penelitian Ponorica \& Al-saedi (2015) merekomendasikan bahwa perlu dibuat kebijakan perpajakan yang sederhana dan meminimalkan biaya kepatuhan pajak. Dalam rangka memberikan kemudahan bagi para pelaku UMKM dalam pemenuhan kewajiban perpajakannya, tahun 2018 lalu pemerintah telah mengeluarkan kebijakan terkait yaitu dengan mengeluarkan Peraturan Pemerintah No 23 Tahun 2018 tentang Pajak Penghasilan atas penghasilan dari usaha yang diterima atau diperoleh Wajib Pajak yang memiliki peredaran bruto tertentu. Peraturan Pemerintah No 23 Tahun 2018 ini berlaku per 1 Juli 2018 menggantikan PP 46 Tahun 2013 dan memberikan pengurangan tarif pajak penghasilan bagi para UMKM dari 1 persen menjadi 0,5 persen. Pengurangan tarif pajak ini bertujuan untuk mendorong peran masyarakat dalam kegiatan ekonomi dan memberi kemudahan dalam melaksanakan kewajiban perpajakan.

Desa Singapadu Tengah dan Singapadu Kaler merupakan salah satu daerah seni dan tujuan wisata di Kabupaten Gianyar dan dikenal oleh wisatawan domestik maupun wisatawan internasional, karena terdapat banyak pengrajin dengan segala macam kerajinannya seperti beraneka ragam jenis patung dari kayu, batu paras, lukisan dan lain sebagainya. Seiring dengan perkembangan pariwisata di Kabupaten Gianyar, masyarakat Desa Singapadu Tengah dan Singapadu Kaler mulai melakukan diversifikasi usaha dari usaha kesenian togog menjadi usaha ekowisata. Pariwisata mulai dilirik sebagai salah satu sektor yang menjanjikan bagi perkembangan wilayah yang memiliki alam yang masih alami, yang tidak hanya mengembangkan aspek lingkungan dalam hal konservasi saja, namun juga memberikan keuntungan bagi masyarakat sekitar, serta sebagai salah satu usaha pengembangan pedesaan untuk meningkatkan perekonomian lokal. Contoh sektor ekowisata di daerah tersebut ialah Kopi Luwak, ATV, dan Rumah Tradisional yang strukturnya terbuat dari tanah liat. Desa Singapadu tidaklah jauh dari kawasan pariwisata yaitu Desa Ubud yang sudah sangat dikenal oleh masyarakat domestik maupun internasional sebagai jantung pariwisata di Kabupaten Gianyar khususnya dan Provinsi Bali pada umumnya. Maka dari itu Desa ini juga mencoba untuk memanfaatkan dan mengembangkan daerah pariwisata karena lokasinya berdekatan dengan Desa Ubud. Dalam penelitian ini, peneliti ingin mengkaji lebih dalam mengenai aspek perpajakan pada sektor usaha ekowisata di daerah tersebut. Pemerintah Kabupaten Giany ar terus melakukan upaya dalam mendorong pengembangan UMKM, karena UMKM memiliki peranan penting dalam peningkatan perekonomian masyarakat dengan dukungan sektor pariwisata. Saat ini, jumlah UMKM di Kabupaten Gianyar mencapai 91 ribu usaha. Dengan bertambahnya jumlah UMKM tersebut, tentunya harus mengikuti aturan yang sudah ditera pkan oleh Pemerintah Pusat dalam aspek perpajakan sebagai upaya untuk memberikan sumbangsih terhadap kehidupan berbangsa dan bernegara. Fakta yang peneliti temukan di lapangan (desa Singapadu Tengah dan Singapadu Kaler) pad a saat 
survey awal, banyak pengusaha UMKM yang belum memiliki NPWP namun memiliki usaha dan enggan untuk membayar pajak.

Mengingat pentingnya kepatuhan Wajib Pajak dalam membayarkan pajaknya serta besarnya potensi UMKM dalam menyumbangkan kontribusin ya dalam hal penerimaan perpajakan, maka penelitian ini bermaksud untuk menguji seberapa jauh kepatuhan Wajib Pajak UMKM Ekowisata di Desa Singapadu Kaler dan Singapadu Tengah pasca aturan PP No 23 Tahun 2018.

\section{METODE PENELITIAN}

Untuk mendapatkan data dengan tujuan dan kegunaan tertentu maka digunakanlah suatu metode penelitian (Sugiyono, 2013:2). Menurut Darmadi (2013:153), metode penelitian adalah suatu cara ilmiah untuk mendapatkan data dengan tujuan kegunaan tertentu. Cara ilmiah berarti kegiatan ilmiah itu didasarkan pada ciri keilmuan yang rasional, empiris dan sistematis. Berdasarkan pemaparan tersebut dapat disimpulkan bahwa metode penelitian adalah suatu cara ilmiah untuk memperoleh data dengan tujuan dan kegunaan tertentu.

Metode penelitian kualitatif sering disebut metode penelitian naturalistik karena penelitiannya dilakukan pada kondisi yang alamiah. Penelitian kualitatif dilakukan pada objek alamiah yang berkembang apa adanya, tidak dimanipulasi oleh peneliti dan kehadiran peneliti tidak begitu memengaruhi dinamika pada objek tersebut. Dalam penelitian ini, penulis menggunakan pendekatan fenomenologi yang bersifat kualitatif, dengan paradigma interpretif sebagai payung penelitian. Fenomenologi adalah pengalaman subjektif atau pengalaman fenomenologikal; atau studi tentang kesadaran dari persepektif pokok dari seseorang (Moleong 2006 :14). Penelitian ini menjelaskan fenomena-fenomena sosial yang ada dengan mengembangkan konsep dan menghimpun fakta, te tapi tidak melakukan pengujian hipotesis. Paradigma Interpretif diturunkan dari Germanic Philosofical Interest yang menekankan pada peranan bahasa, interpretasi dan pemahaman.

Pengujian validitas data dalam penelitian kualitatif dapat dilakukan melalui perpanjangan pengamatan, peningkatan ketekunan dalam penelitian, triangulasi, diskusi dengan teman sejawat, analisis kasus negatif dan membercheck. Penelitian ini menggunakan triangulasi sumber yaitu dengan cara mengecek data yang telah diperoleh melalui beberapa sumber pada lokasi penelitian. Sumber wawancara dalam penelitian ini selain informan dari pemilik UMKM sektor Ekowisata, mitra bisnis pemilik Usaha Sektor Ekowisata yang mengetahui kondisi usaha tersebut dan Direktorat Jendral Pajak Kantor Pelayanan Pajak Pratama Kabupaten Gianyar. Dalam penelitian ini informan sudah ditentukan terlebih dahulu oleh penulis untuk memastikan terdapat perubahan gejala usaha yang dahulunya sebagai pengusaha bidang patung dan kini merambat kedunia ekowisata. Informan dalam penelitian berjumlah 14 orang yang merupakan pelaku UMKM khususnya di bidang kerajinan tangan (ukir), kopi, dan ATV maupun Wisata Alam, serta informan dari Account Representative (AR) KPP Pratama Gianyar yang menangani wilayah Singapadu Tengah dan Singapadu Kaler. 
Penelitian ini bertujuan untuk mengkaji kepatuhan Wajib Pajak pasca aturan PP No 23 Tahun 2018 pada pelaku UMKM Ekowisata di Desa Singa pad u Kaler dan Singapadu Tengah. Untuk itu, peneliti harus melakukan penga matan dan langsung ke tempat usaha UMKM sektor ekowisata untuk mengetahui kondisi bisnis serta informasi perpajakan yang diketahui oleh wajib pajak pengusaha UMKM ekowisata.

\section{HASIL DAN PEMBAHASAN}

Dari 5 tahun terakhir, jumlah Wajib Pajak UMKM khususnya di Kabupaten Gianyar selalu mengalami peningkatan. Peningkatan lebih dari 100 persen wajib pajak dari tahun 2015 sampai 2019 yang menandakan bahwa pelaku UMKM sadar dalam melakukan pembayaran pajak khususnya dibidang usaha yang digeluti. KPP Pratama Gianyar mencatat terdapat 12.279 wajib pajak sampai bulan September 2019 dan memungkinkan terjadi penambahan sampai akhir tahun 2019 dengan diimbangi dengan pernyataan Presiden agar meningkatkan industri kreatif dan inovatif serta pemusatan kembali ke sektor desa yang memungkinkan terjadi pendanaan UMKM serta kebijakan yang sudah lama diaktifkan kembali yaitu OVOP (One Village One Product). Jumlah Wajib Pajak UMKM di Kabupaten Gianyar dari tahun 2015 sampai 2019 ditunjukkan pada Tabel 3 .

Tabel 3. Jumlah Wajib Pajak UMKM Gianyar

\begin{tabular}{cc}
\hline Tahun & Jumlah Wajib Pajak UMKM \\
\hline 2015 & 5.517 \\
2016 & 6.264 \\
2017 & 8.072 \\
2018 & 11.189 \\
2019 & 12.279 \\
\hline
\end{tabular}

Sumber: Data Penelitian, 2019

Penerimaan pajak 5 tahun terakhir berdasarkan data yang diperoleh dari KPP Pratama Gianyar mengalami penurunan dalam 2 tahun terakhir yaitu di tahun 2018 dan juga tahun 2019 (data per 16 September 2019). Tabel 4. menjelaskan peningkatan penerimaan pajak UMKM dari tahun 2015 ke tahun 2017 di KPP Pratama Gianyar dan mengalami penurunan di tahun 2018 meskipun tidak terlalu signifikan.

Tabel 4. Penerimaan Pajak UMKM di KPP Pratama Gianyar

\begin{tabular}{cc}
\hline Tahun & PenerimaanUMKM $(\mathrm{Rp})$ \\
\hline 2015 & 18.682 .875 .719 \\
2016 & 21.779 .167 .110 \\
2017 & 29.860 .810 .229 \\
2018 & 29.797 .170 .189 \\
2019 & 20.620 .798 .782 \\
Total & 120.740 .822 .029 \\
\hline
\end{tabular}

Sumber: Data Penelitian, 2019

Kepatuhan wajib pajak, sosialisasi, dan pengetahuan tentang PP No 23 tahun 2018 merupakan hal yang harus dipahami oleh pelaku UMKM. Ketiga hal 
ini menjadi poin penting bagi pelaku UMKM dalam menjalankan usahanya agar memahami dan mengerti koridor tentang perpajakan kedepan, serta merasa aman dan nyaman dalam menjalankan usahanya. Kepatuhan wajib pajak dalam pembayaran pajak pasca aturan PP No 23 Tahun 2018 menunjukkan hasil positif, dari 14 UMKM yang diwawancarai, hanya terdapat 2 UMKM yang tidak patuh dalam pembayaran dikarenakan tidak mengetahui aturan perpajakan yang berlaku serta tata cara pembayaran pajak. Hasil tersebut menunjukkan bahwa sekitar 85 persen UMKM yang menjadi sampel dalam penelitian ini patuh membayar pajak. Hasil tersebut sejalan dengan pernyataan dari (Maulinarhadi, Kertahadi, \& Mustofa, 2016) yaitu sejauh mana wajib pajak dapat melaksanakan kewajiban perpajakannya dengan baik dan benar sesuai peraturan perpajakan.

Singapadu Kaler merupakan desa yang sudah memperoleh status sebagai desa wisata, sehingga lebih mudah dalam memasarkan produk khususnya bidang pariwisata. Kepatuhan wajib pajak secara tidak langsung dapat meningkatkan angka kesejahteraan Singapadu Kaler sebagai desa wisata karena pelaku usaha sebagian besar adalah masyarakat lokal yang secara swadaya menghimpun usaha tersebut. Status Desa Wisata menjadi incaran banyak desa. Keunggulan desa wisata di Singapadu Kaler merupakan salah satu aspek jual desa dalam mengembangkan produk wisata alam, khususnya usaha ATV, Kokat, dan Kopi yang sedang menjadi wisata primadona khususnya tamu mancanegara. Kepatuhan wajib pajak menyentuh angka 85 persen, dikarenakan pelaku usaha rata-rata melakukan pembayaran pajak secara mandiri dan hal ini telah sesuai dengan salah satu prinsip perpajakan di Indonesia yaitu menghitung, membayar dan melapor pajak secara mandiri atau dikenal dengan istilah Self Assessment System. Keberhasilan sistem self-assessment ini sangat bergantung pada kesadaran dan peran serta masyarakat. Edukasi dan komunikasi perlu terus menerus dilakukan. Di samping itu, kepercayaan pada pemerintah dan otoritas pajak perlu terus dipupuk melalui pembentukan badan penerimaan negara yang professional, kredibel, dan akuntabel serta redistribusi pendapatan yang merata dan berkeadilan (Kirchler, Hoelzl, \& Wahl, 2008) dan (Riahi-Belkaoui, 2008). Tulang punggung dari Self Assessment System yaitu kepatuhan memenuhi kewajiban pajak secara sukarela (Noor dan Kasipillai, 2013). Dapat disimpulkan bahwa pelaku usaha memiliki kepatuhan dalam melakukan pembayaran pajak.

Berdasarkan temuan di lapangan, belum pernah dilakukan sosialisasi mengenai PP No. 23 Tahun 2018 secara langsung dari Kantor Pelayanan Pajak (KPP) Pratama Gianyar ke Desa Singapadu Tengah dan Singapadu Kaler. Dari survey, wawancara serta pendataan dilapangan oleh peneliti, 100 persen atau semua pelaku UMKM yang menjadi sampel penelitian di Desa Singapadu Kaler dan Singapadu Tengah tidak pernah mendapatkan sosialisasi secara langsung tentang peraturan PP No 23 Tahun 2018. Hal tersebut dibenarkan oleh Pande selaku Account Representative (AR) dari Kantor Pelayanan Pajak Pratama Gianyar yang memberikan pendapat:

"Iya benar, bahwa kita belum pernah melakukan sosialisasi kepada pelaku usaha mikro kecil dan menengah baru di desa Singapadu Tengah dan Singapadu Kaler, kita hanya mengawasi dan menghimbau tentang kewajiban masayarakat dalam pelaporan SPT tahunan sesuai dengan data yang kita miliki. Sebagian data 
belum sepenuhnya update karena secara perijinan usaha didaerah tersebut hanya memiliki ijin usaha atau surat keterangan usaha dibawah banjar tau desa saja. Kita sudah mendatangi pelaku usaha yang terdaftar sebagian di kantor kami KPP Pratama Gianyar".

Sosialisasi yang pernah dilakukan bukan dari KPP Pratama Gianyar, melainkan hanya pembinaan usaha dari Pemerintahan Desa setempat dan Pemerintah Daerah Gianyar. Maka dapat disimpulkan bahwa data yang tidak update dari desa dan sosialisasi yang belum pernah dilakukan oleh petugas pajak menjadi salah satu kendala dalam melakukan sosialisai PP No 23 Tahun 2018, sehingga perlu adanya sinergitas antara pelaku usaha, aparatur desa, dan juga petugas perpajakan.

Berdasarkan hasil wawancara dengan informan di lapangan mengenai pengetahuan tentang PP No 23 Tahun 2018, menunjukkan terdapat 8 pelaku UMKM atau sebesar 57 persen dari 14 pelaku UMKM yang mengetahui tentang PP No 23 Tahun 2018. Angka ini tergolong minim untuk mewakili seluruh pelaku usaha UMKM di dua desa tersebut. Desa Singapadu Tengah dan Singapadu Kaler memilki jumlah UMKM dibidang ekowisata yang cukup banyak dan terbilang unggulan dibandingkan desa di Kecamatan Sukawati lainnya. (Palil, 2005) menyatakan bahwa ketika seseorang wajib pajak memiliki pengetahuan perpajakan yang baik, sikap terhadap pajak akan lebih positif dan dapat meningkatkan kepatuhan dan mengurangi kecurangan menghindari pajak. Pengetahuan dasar tentang perpajakan menjadi suatu keharusan bagi pelaku usaha khususnya UMKM. Hal ini penting agar para pelaku usaha terhindar dari kesulitan dalam perhitungan angka nantinya, disamping itu wajib pajak juga tidak mudah dibohongi oleh oknum-oknum yang mengatasnamakan petugas pajak. Peraturan Pemerintah No 23 Tahun 2018 ini berlaku per 1 Juli 2018 menggantikan PP No 46 Tahun 2013 yang memberikan pengur angan tarif pajak penghasilan final bagi UMKM dari 1 persen menjadi 0,5 persen dari omzet. Tarif ini diperuntukkan bagi UMKM yang memiliki omzet kurang dari Rp 4,8 miliar dalam setahun. Pengurangan tarif pajak ini bertujuan untuk mendorong peran masyarakat dalam kegiatan ekonomi dan memberi kemudahan dalam melaksanakan kewajiban perpajakan. Kebijakan ini merupakan stimulus bagi pelaku UMKM agar pelaku bisa mengembangkan bisnisnya serta melakukan ekspansi usaha. Tarif pajak tersebut diharapkan memberikan ketersediaan dan kemauan pelaku usaha agar patuh dalam hal membayar dan melaporkan pajaknya agar realisasi penerimaan pajak dapat meningkat.

\section{SIMPULAN}

Angka kepatuhan wajib pajak pasca aturan PP No 23 Tahun 2018 pada pelaku UMKM Ekowisata di Desa Singapadu Tengah dan Singapadu Kaler mencapai angka 85 persen, dimana dapat disimpulkan bahwa pelaku UMKM patuh melakukan pembayaran pajak. Sekitar 15 persen wajib pajak atau pelaku UMKM tidak melakukan pembayaran pajak usaha tersebut dikarenakan sebagian telah tutup dan beralih profesi bidang lain. Sosialisasi PP No 23 Tahun 2018, dari temuan dilapangan tidak terdapat sosialiasi secara langsung. Pihak KPP Pratama Gianyar tidak pernah melakukan sosialisasi tentang PP No 23 Tahun 2018 kepada pelaku usaha UMKM Ekowisata di Desa Singapadu Kaler dan Singapadu 
Tengah. Pengetahuan tentang PP No 23 Tahun 2018 terhadap pelaku usaha di Desa Singapadu Kaler dan Singapadu Tengah tergolong minim yaitu sekitar 57 Persen. Pelaku UMKM yang memiliki pengetahuan tentang PP No 23 Tahun 2018 sebagian besar mendapatkan pengetahuan dari media internet dan konsultasi pada Konsultan Pajak.

Adapun saran yang diberikan penulis dalam penelitian ini adalah Sosialisasi PP No 23 Tahun 2018 dan aturan terbaru tentang perpajakan perlu dilakukan kepada pelaku UMKM Ekowisata khususnya di Desa Singapadu Kaler dan Singapadu Tengah. Dengan adanya sosialisasi tersebut akan menghasilkan pengetahuan bagi Wajib Pajak dan diharapkan meningkatkan kepatuhan perpajakan.

\section{REFERENSI}

Atawodi, O. W., \& Ojeka, S. A. (2012). Relationship between Tax Policy, Growth of SMEs and the Nigerian Economy. International Journal of Business and Management. https://doi.org/10.5539/ijbm.v7n13p125

DJP. (2018). Laporan Tahunan 2018 Direktorat Jenderal Pajak. Sinergi Menuju Kemandirian Ekonomi Nasional, 1-250. Retrieved from https://www.pajak.go.id/sites/default/files/2019-11/Laporan Tahunan DJP 2018 - bahasa Indonesia.pdf

Endrianto, W. (2015). Prinsip Keadilan dalam Pajak atas UMKM. Binus Business Review. https://doi.org/10.21512/bbr.v6i2.978

Fajriyan, Nur Afianti. (2015). Pengaruh Persepsi Pelaksanaan Sensus Pajak Nasional, Sikap Wajib Pajak Pada Pelaksanaan Sanksi Denda Dan Kesadaran Perpajakan Terhadap Kepatuhan Wajib Pajak (Studi Pada Wajib Pajak Orang Pribadi Di Kelurahan Miji Kota Mojokerto). Jurnal Universitas Brawijaya.

Gbegi, D. ., \& Adebisi, J. . (2013). the New Fraud Diamond Model- How Can It Help Forensic Accountants in Fraud Investigation in Nigeria? European Journal of Accounting Auditing and Finance Research. https://doi.org/10.1017/CBO9781107415324.004

https://www.pajak.go.id/id/laporan-tahunan-2017

https://www.kemenkeu.go.id/apbn2018

Inasius, F. (2014). Kebijakan Angsuran Pajak Penghasilan Wajib Pajak Orang Pribadi Pengusaha Tertentu: Studi Kasus Usaha Mikro di Indonesia. Binus Business Review. https://doi.org/10.21512/bbr.v5i1.1210

James, S., \& Alley, C. (2002). Tax compliance, self-assessment and tax administration. Journal of Finance and Management in Public Services.

Kementerian Koperasi dan UKM. 2018 Tentang Pelaku UMKM.

Kirchler, E., Hoelzl, E., \& Wahl, I. (2008). Enforced versus voluntary tax compliance: The "slippery slope" framew ork. Journal of Economic Psychology. https://doi.org/10.1016/j.joep.2007.05.004

Lazuardini, E. R., Susyanti, J., \& Priyono, A. A. (2018). Pengaruh Pemahaman Peraturan Perpajakan, Tarif Pajak Dan Sanksi Pajak Terhadap Kepatuhan Wajib Pajak Umkm (Studi Pada Wajib Pajak Orang Pribadi Yang Terdaftar di KPP Pratama Malang Selatan). E - Jurnal Riset Manajemen. https://doi.org/10.1123/ijsb.8.1.1 
Mardiasmo. (2009). Perpajakan Edisi Revisi 2009. Yogyakarta: Andi.

Maulinarhadi, M., Kertahadi, \& Mustofa, F. A. (2016). Pengaruh Pemahaman Peraturan Perpajakan, Tarif Pajak Dan Asas Keadilan Terhadap Kepatuhan Wajib Pajak. Journal of Chemical Information and Modeling. https://doi.org/10.1017/CBO9781107415324.004

Moleong, Lexy J. (2013). Metode Penelitian Kualitatif. Edisi Revisi. Bandung : PT. Remaja Rosdakarya.

Mwangi, M., \& Nganga, I. (2006). Taxation and SME's Sector Growth. Asian Journal of Business and Management Sciences, 2(3), 1-7.

Noor Sharoja Sapiei dan Jeyapalan Kasipillai. (2013). Impacts of the SelfAssessment System for Corporate Taxpayers. American Journal of Economics 2013, 3(2): 75-81 DOI: 10.5923/j.economics.20130302.03.

Palil, M. R. (2005). Taxpayers Knowledge: A Descriptive Evidence On Demographic Factors In Malaysia. Jurnal Akuntansi Dan Keuangan. https://doi.org/10.9744/jak.7.1.pp.11-21

Ponorîcă, A. G., \& Al-saedi, A. H. J. (2015). The Importance of Taxation Systems for SME Tax Compliance. In Proceeding of the 9th International Management Conference "Management and Innovation For Competitive Advantage", November 5th-6th, 2015, Bucharest, Romania (pp. 129-136).

Peraturan Menteri Keuangan Nomor 192/PMK.03/2007 tentang Tata Cara Penetapan Wajib Pajak dengan Kriteria Tertentu dalam Rangka Pengembalian Pendahuluan Kelebihan Pembayaran Pajak.

Peraturan Pemerintah Nomor 23 Tahun 2018 tentang Pajak Penghasilan Dari Usaha yang Diterima atau Diperoleh Wajib Pajak yang Memiliki Peredaran Bruto Tertentu.

Riahi-Belkaoui, A. (2008). Bureaucracy, Corruption and Tax Compliance. In Taxation and Public Finance in Transition and Developing Economies. https://doi.org/10.1007/978-0-387-25712-9_1

Rini, F. L. E. (2015). Penyusunan dan penyajian laporan keuangan berbasis SAK ETAP (Studi kasus pada UMKM Ekspedisi CV Mandiri ). Akuntansi. https://doi.org/10.1007/s00464-010-1262-0

Sari, Rafika. (2018). Kebijakan Insentif Pajak Bagi Usaha Mikro Kecil dan Menengah. Pusat Penelitian Badan Keahlian DPR RI.

Simanjuntak, Timbul H dan Imam Mukhlis. (2012). Dimensi Ekonomi Perpajakan dalam Pembangunan Ekonomi. Jakarta: Raih Asa Sukses

Stone, E. H. (1978). Visual Resource Management. Amer. Soc. Of Landscape Arch., Washington, D. C. 32p

Sugiyono. (2013). Metode Penelitian Kuantitatif, Kualitatif dan RED. Cetakan ke-19. Bandung: Alfabeta

Tatik. (2018). Potensi Kepatuhan Pembayaran Pajak Pada Pelaku Umkm (Usaha Mikro Kecil Dan Menengah) Pasca Penerbitan Peraturan Pemerintah Nomor 23 Tahun 2018 Yogyakarta). Seminar Nasional Dan Call For Paper Sustainable Competitive Advantage (SCA).

Undang-Undang Nomor 16 Tahun 2009 Tentang Ketentuan Umum dan Tata Cara Perpajakan. 